\title{
Recovery of Biomass Following Shifting Cultivation in Dry Tropical Forests of the Yucatan
}

\section{Citation}

Read, L., Lawrence, D., Foster, D. R. 2003. Recovery of biomass following shifting cultivation in the Southern Yucatan. Ecological Applications 13: 85-97.

\section{Published Version}

http://www.jstor.org/stable/3099952

\section{Permanent link}

http://nrs.harvard.edu/urn-3:HUL.InstRepos:30653605

\section{Terms of Use}

This article was downloaded from Harvard University's DASH repository, and is made available under the terms and conditions applicable to Other Posted Material, as set forth at http:// nrs.harvard.edu/urn-3:HUL.InstRepos:dash.current.terms-of-use\#LAA

\section{Share Your Story}

The Harvard community has made this article openly available.

Please share how this access benefits you. Submit a story.

Accessibility 


\title{
RECOVERY OF BIOMASS FOLLOWING SHIFTING CULTIVATION IN DRY TROPICAL FORESTS OF THE YUCATAN
}

\author{
LARISSA READ ${ }^{1}$ AND Deborah LAWRENCE ${ }^{1,2,3}$ \\ ${ }^{1}$ Department of Environmental Sciences, University of Virginia, Clark Hall, P.O. Box 400123, \\ Charlottesville, Virginia 22904-4123 USA \\ ${ }^{2}$ Harvard Forest, Harvard University, 324 Main Street, Petersham, Massachusetts 01366 USA
}

\begin{abstract}
Land-use change in the tropics is creating secondary forest at an unprecedented rate. In the tropical Americas, mature dry tropical forest is rapidly being converted to secondary forest during the fallow period of shifting cultivation. This study addresses changes in forest biomass during forest recovery following shifting cultivation of maize (corn) in the Southern Yucatan Peninsular Region (SYPR), Mexico. We sampled stems $>1$ $\mathrm{cm}$ diameter at breast height at 36 study sites in three regions located along a precipitation gradient of 900-1400 mm/yr. Using allometric equations developed in the tropical Americas, we estimated total aboveground (TAG) biomass of trees, palms, and lianas. Biomass differed little between regions when considering forests of a given age. Over the entire area, forest biomass increased rapidly during succession, from $20.9 \mathrm{Mg} / \mathrm{ha}$ in 2-5-yr-old forests to $136.4 \mathrm{Mg} / \mathrm{ha}$ in mature forests (logged in the past half century, but not cultivated). Within 12-25 yr, biomass reached half of mature forest levels, and we estimate recovery to precultivation levels in 55-95 yr. Recovery to a pre-logged state may take 65-120 yr. In mature forests, the contribution of stems $1-4.9 \mathrm{~cm}$ dbh was consequential, comprising $15 \%$ of TAG biomass. Trends in both TAG biomass and basal area were driven by the contribution of trees, although in a few sites, the importance of palms and lianas to forest structure and biomass was considerable. Our results suggest that forest biomass in secondary dry tropical forests of the SYPR is profoundly influenced by forest age, and less so by annual precipitation, while variability in forest structure depends more on differences in water availability and recent human disturbance.
\end{abstract}

Key words: biomass; dry tropical forest; land-use change; secondary forest; shifting cultivation; Yucatan Peninsula, Mexico.

\section{INTRODUCTION}

The recognition that tropical secondary forests are rapidly being created through land-use change, and will continue to play a major role in the tropical landscape (Brown and Lugo 1990), has spurred investigations of their ecosystem dynamics. In the tropics of Mexico, an effort to understand the contribution of tropical secondary forests to the global carbon cycle has prompted research to accurately quantify forest biomass, carbon flux, and rates of deforestation and recovery following disturbance (Brown et al. 1989, Cairns et al. 2000, Hughes et al. 2000, Trejo and Dirzo 2000). In view of the considerable literature on biomass and carbon flux in wet tropical forests, ecosystem dynamics and biomass in the dry tropics remain largely unquantified (but see Arnason and Lambert 1982, Murphy and Lugo 1986b, Martinez-Yrizar and Sarukhan 1990, Whigham et al. 1990, Castellanos et al. 1991, Martinez-Yrizar et al. 1992, Kauffman et al. 1993).

Dry tropical forest covers $8 \%$ of Mexico, where shifting cultivation is rapidly creating large areas of secondary forest (Martinez-Yrizar and Sarukhan 1990,

Manuscript received 15 October 2001; revised and accepted 3 May 2002. Corresponding Editor: S. Brown

${ }^{3}$ Corresponding author. E-mail: lawrence@virginia.edu
Martinez-Yrizar et al. 1992, Trejo and Dirzo 2000, Turner et al. 2001). The total area of agricultural systems in tropical Mexico increased by $64 \%$ during the period 1977-1992, with a mean annual deforestation rate of $1.9 \%$ (Cairns et al. 2000). Recent work in Mexican tropical forests has also demonstrated their potential for both carbon sequestration through rapid production of woody material and litter, and carbon loss to the atmosphere through continued conversion (Brown and Lugo 1990, Whigham et al. 1990, Hughes et al. 1999, Cairns et al. 2000).

Accurate quantification of the accumulation and storage of biomass in tropical secondary forests is particularly difficult due to the complex dynamics that regulate and constrain their recovery, such as changes in species composition and forest structure during succession (Ewel 1980, Brown and Lugo 1990). Previously, most studies of tropical forest biomass were centered on commercially important, mature forest species, but more recently, the roles of successional species and non-tree species in rapid carbon accumulation of tropical secondary forests have been recognized (Putz 1983, Brown and Lugo 1990, Nelson et al. 1999, Gerwing and Lopes Farias 2000).

Most secondary forests in the tropical Americas are created due to human activity, such as shifting culti- 


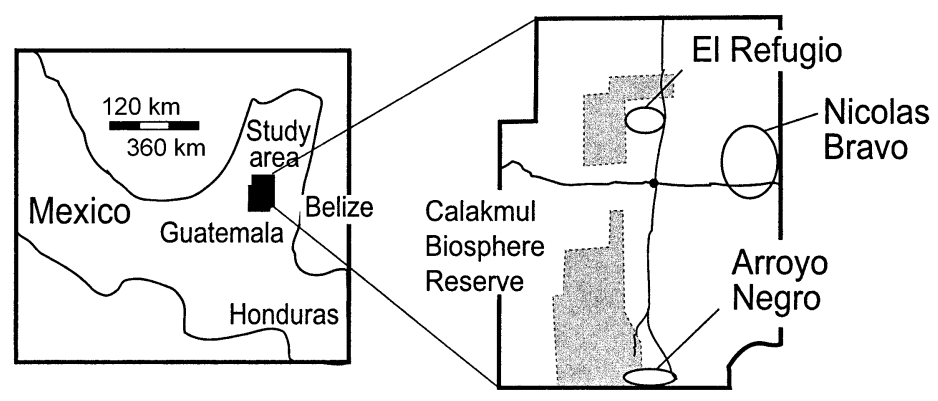

FIG. 1. Map of study regions in the Southern Yucatan Peninsula, Mexico. The Calakmul Biosphere Reserve is represented by the two shaded areas.

vation, pasture installation and abandonment, and harvest of forest products. These anthropogenic factors are often difficult to quantify and the effects of various land-use changes on recovery of tropical forests remain understudied (see Uhl and Jordan 1984, Buschbacher et al. 1988, Hughes et al. 2000). Despite these complexities, it is critical that we accurately estimate biomass accumulation in these forests in order to assess their contribution to the global carbon cycle and to mitigate destruction of primary tropical forests through prudent management of secondary tropical forests (Brown and Lugo 1990).

The major objectives of this study were to: (1) quantify changes in forest biomass in the Southern Yucatan Peninsular Region (SYPR; Fig. 1) during recovery from shifting cultivation, (2) investigate variability in biomass over a regional precipitation gradient, and (3) estimate time to recovery of secondary forest biomass to pre-cultivation forest levels. We estimated total aboveground (TAG) biomass for dry tropical forests in the SYPR using existing biomass equations for the tropical Americas. We explored patterns in forest biomass along a regional precipitation gradient of $\sim 900-$ $1400 \mathrm{~mm} / \mathrm{yr}$ and a successional gradient ranging from 2 to $25 \mathrm{yr}$ since abandonment from maize agriculture, plus several mature forests. Using a space-for-time approach, our study of successional biomass dynamics also allowed us to investigate the rate of recovery of these forests following shifting cultivation. Additionally, we compared tree heights and basal area among regions and over the successional gradient in order to assess their potential role as drivers of forest biomass variability. Finally, we investigated differences in stem density and their contribution to forest biomass over the same gradients as an indication of changes in forest structure during recovery.

\section{Methods \\ Study area and its land-use history}

Human presence in the SYPR has shaped the landscape at both local and regional scales. The SYPR was subject to intense agriculture during Mayan times until $\sim 1100$ yr ago (Turner 1974). Recent disturbance, including chicle production in the early 1900 s and selective logging beginning in the 1950s, was not consequential until the 1960s (Klepeis 2000). The opening of a highway through the region in 1967, combined with incentives for agricultural development, resulted in an influx of colonists from other regions of Mexico to participate in chicle, maize, and government-sponsored wet-rice production. Development of the ejido system, a collective farming initiative promoted by the government, led to rapid conversion of mature forest to agricultural land in the 1970s (Klepeis 2000). Sustained migration of settlers into the SYPR, coupled with efforts to shift the current agricultural system from subsistence to market-oriented farming, is likely to increase the rate of land-use change in the region (Klepeis 2000). Natural disturbances in the region include fires and hurricanes, such as Hurricane Gilbert in 1988 (Boose et al. 1994, Harmon et al. 1995).

TABle 1. Edaphic characteristics (mean $\pm 1 \mathrm{SE}$ ) of surface soils from the Southern Yucatan Peninsular Region, Mexico.

\begin{tabular}{|c|c|c|c|c|c|c|}
\hline \multirow[b]{2}{*}{ Characteristic } & \multicolumn{2}{|c|}{ E1 Refugio } & \multicolumn{2}{|c|}{ Nicolas Bravo } & \multicolumn{2}{|c|}{ Arroyo Negro } \\
\hline & $\begin{array}{l}\text { Secondary } \\
\text { sites }\end{array}$ & $\begin{array}{c}\text { Mature } \\
\text { forest sites }\end{array}$ & $\begin{array}{l}\text { Secondary } \\
\text { sites }\end{array}$ & $\begin{array}{c}\text { Mature } \\
\text { forest sites }\end{array}$ & $\begin{array}{l}\text { Secondary } \\
\text { sites }\end{array}$ & $\begin{array}{c}\text { Mature } \\
\text { forest sites }\end{array}$ \\
\hline Clay (\%) & $35 \pm 4$ & $23 \pm 4$ & $30 \pm$ & $20 \pm 6$ & $26 \pm 2$ & $14 \pm 1$ \\
\hline Silt $(\%)$ & $36 \pm 3$ & $25 \pm 4$ & $35 \pm 3$ & $33 \pm 4$ & $30 \pm 5$ & $27 \pm 3$ \\
\hline Sand $(\%)$ & $30 \pm 3$ & $51 \pm 2$ & $35 \pm 3$ & $47 \pm 2$ & $45 \pm 4$ & $59 \pm 2$ \\
\hline Organic matter (\%) & $10.7 \pm 0.6$ & $11.4 \pm 1.1$ & $11.6 \pm 0.9$ & $14.5 \pm 0.6$ & $11.1 \pm 0.4$ & $21.8 \pm 5.6$ \\
\hline $\mathrm{pH}$ & $7.5 \pm 0.1$ & $7.7 \pm 0.0$ & $7.4 \pm 0.1$ & $7.4 \pm 0.1$ & $7.8 \pm 0.1$ & $7.7 \pm 0.1$ \\
\hline $\begin{array}{l}\text { Total exchangeable } \\
\text { cations }\left(\mathrm{mmol}_{\mathrm{c}} / \mathrm{g}\right)\end{array}$ & $84 \pm 13$ & $134 \pm 18$ & $66 \pm 10$ & $54 \pm 10$ & $114 \pm 16$ & $139 \pm 41$ \\
\hline
\end{tabular}

Notes: Data are based on composite soil samples (32) per site drawn from a depth of $15 \mathrm{~cm}$. For numbers and ages of sites, see Methods: Study area and its land-use history, Field sampling, and Table 2. Data are modified from Lawrence and Foster (2002). 
Regionally, soils are shallow, calcareous, and highly permeable due to organic matter content and underlying limestone bedrock (Whigham et al. 1990). Preliminary soil nutrient analyses from our study sites indicate that both sand and organic matter content increase with increasing precipitation and forest age (Table 1; Lawrence and Foster 2002).

Climate in the dry forests of the Yucatan Peninsula is characterized by a regional mean annual temperature of $25^{\circ} \mathrm{C}$ and highly variable precipitation on both seasonal and annual time scales (Harmon et al. 1995, Whigham et al. 1990). In our study area, precipitation ranges from $\sim 900$ to $1400 \mathrm{~mm} / \mathrm{yr}$. Across the study region, the rainy season extends from July to December, with peak rainfall occurring in September/October (Turner et al. 2001).

Three study regions were chosen $60-120 \mathrm{~km}$ apart along a precipitation gradient (Fig. 1, Table 2): the driest and northernmost study region, El Refugio (ER; $\left.18^{\circ} 49^{\prime} \mathrm{N}, 89^{\circ} 23^{\prime} \mathrm{W}\right)$, the centrally located Nicolas Bravo $\left(\mathrm{NB} ; 18^{\circ} 27^{\prime} \mathrm{N}, 88^{\circ} 56^{\prime} \mathrm{W}\right)$, and the southern, wettest region Arroyo Negro (AN; $17^{\circ} 53^{\prime} \mathrm{N}, 89^{\circ} 17^{\prime} \mathrm{W}$ ). For the past $15 \mathrm{yr}$, the mean length of the anuual dry season $(<50 \mathrm{~mm} / \mathrm{mo})$ has been three months in Arroyo Negro, three to four months in Nicolas Bravo, and six months in El Refugio. Monthly precipitation during the wet season increases from north to south with mean of 95 , 118, and $136 \mathrm{~mm} / \mathrm{mo}$ in El Refugio, Nicolas Bravo, and Arroyo Negro, respectively (data courtesy of INEGI [El Instituto Nacional de Estadística, Geografía e Informática], Mexico; available online). ${ }^{4}$ Preliminary results from the SYPR indicate that peak litterfall occurs in March at all sites of the study region, but seasonality in litter production was least pronounced in the southern, wettest region Arroyo Negro (Whigham et al. 1990; D. Lawrence, unpublished manuscript).

Differences in precipitation regime have led to modest differences in the floristic composition of both mature and secondary forests (Table 3). Estimates of stem density indicate that the most abundant species in secondary forest was not shared across the three study regions (Table 3); however, four of the top ten were common to all regions. A similar pattern was found in mature forest, except that the most abundant species (Myrciaria floribunda) dominated in all three regions (Table 3). A more extensive sample of trees $>5 \mathrm{~cm}$ $\mathrm{dbh}$ in mature forests (from 10-12 500- $\mathrm{m}^{2}$ plots in each region) revealed that all the tree species present in the wettest site are also found in the driest site, with an additional complement of species observed only in the driest site (D. Perez-Salicrup, personal communication). Considering relative basal area, frequency, and abundance in the more extensive sample, four of the top ten tree species are shared between the wettest and driest sites (Brosimum alicastrum, Bursera simaruba,

${ }^{4}$ URL: 〈www.inegi.gob.mx/difusion/ingles/portadai.html〉
TABLE 2. Land-use history (owner, age, and cultivation intensity), location, and precipitation of the 36 sampling sites in the Southern Yucatan Peninsula Region (SYPR), Mexico.

\begin{tabular}{|c|c|c|}
\hline Site name & Age & $\begin{array}{c}\text { No. yr } \\
\text { cultivated }\end{array}$ \\
\hline \multicolumn{3}{|c|}{ E1 Refugio (13 sites; $892 \mathrm{~mm} / \mathrm{yr}) \dagger$} \\
\hline Hermelindo & 2 & 5 \\
\hline Juventino & 3 & 3 \\
\hline Juan & 4 & 5 \\
\hline Hermelindo & 5 & 2 \\
\hline Rufino & 8 & 2 \\
\hline Juan & 8 & 4 \\
\hline Juventino & 10 & 2 \\
\hline Juan & 12 & 1 \\
\hline Hermelindo & 12 & 2 \\
\hline Juventino & 12 & 2 \\
\hline Victor & mature & 0 \\
\hline Camino Principal & mature & 0 \\
\hline Roberto & mature & 0 \\
\hline \multicolumn{3}{|c|}{ Nicolas Bravo (13 sites; $1144 \mathrm{~mm} / \mathrm{yr}) \dagger$} \\
\hline Agustin & 3 & $4 ?$ \\
\hline Pedro & 5 & 4 \\
\hline Enrique & 5 & $2+$ \\
\hline Agustin & 6 & $4 ?$ \\
\hline Benito & 8 & 4 \\
\hline Pedro & 16 & 4 \\
\hline Benito & 18 & 2 \\
\hline Pedro & 24 & 1 \\
\hline Enrique & 25 & 1 \\
\hline Agustin & 25 & 1 \\
\hline NB1 & mature & 0 \\
\hline NB2 & mature & 0 \\
\hline Calakmulita & mature & 0 \\
\hline \multicolumn{3}{|c|}{ Arroyo Negro (10 sites; $1418 \mathrm{~mm} / \mathrm{yr}) \dagger$} \\
\hline Antonio & 4 & 7 \\
\hline Fermin & 5 & 4 \\
\hline Gilberto & 5 & 1 \\
\hline Gilberto & 7 & 1 \\
\hline Antonio & 8 & $3+$ \\
\hline Fermin & 9 & $3+$ \\
\hline Fermin & 15 & $2+$ \\
\hline Antonio & 18 & 2 \\
\hline Antonio & mature & 0 \\
\hline Jose & mature & 0 \\
\hline
\end{tabular}

Note: Data from 1986-1998 are available online (INEGI, Mexico; see footnote 4).

$\uparrow$ Number of sites and median annual precipitation are given in parentheses for each study region. Median annual precipitation is reported in order to avoid bias due to hurricanes. \$ Age of successional forest in January 1999 .

$\S$ Total years in maize cultivation, which may have been distributed over one or more cultivation-fallow cycles.

Manilkara zapota, and Ampelocera hottlei; D. PerezSalicrup, personal communication).

\section{Research design}

Within each study region, 10-13 500- $\mathrm{m}^{2}$ circular plots (Table 2) were arrayed in a successional sequence of secondary forest ranging from 2 to $25 \mathrm{yr}$ since abandonment from maize agriculture, plus several mature forests of unknown age. All sites were subject to documented maize cultivation, with no chemical inputs. Most of the sites were probably subject to periodic 
TABLE 3. Most abundant species in sample plots of each region based on stem density of trees $>1 \mathrm{~cm} \mathrm{dbh}$.

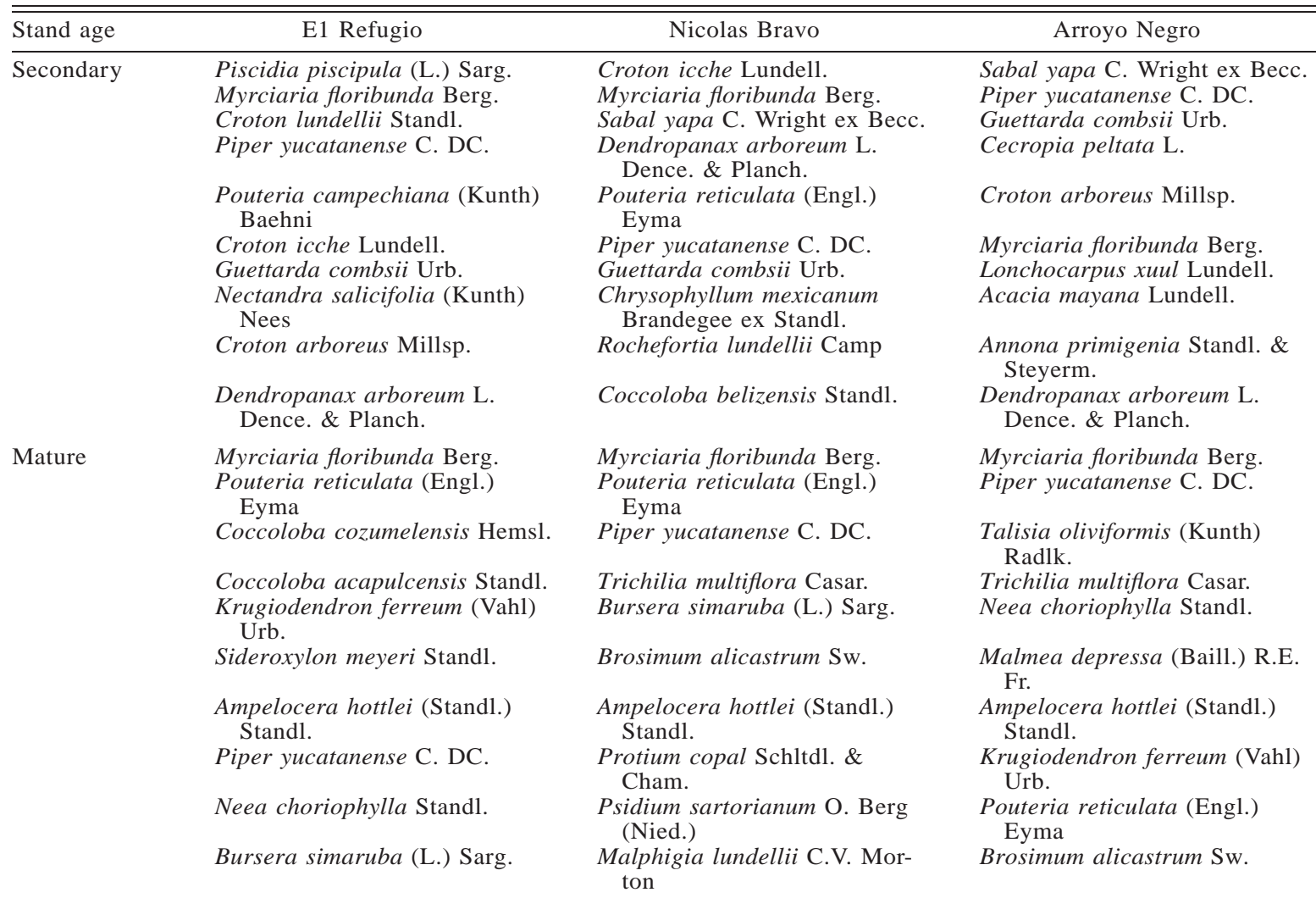

Notes: Stem density was calculated from identification of stems in $10-\mathrm{m}^{2}, 100-\mathrm{m}^{2}$, and $500-\mathrm{m}^{2}$ plots (see Methods: Field sampling). Stem density was from sample plots was then scaled to density per hectare. The top ten species in each category are listed in order of decreasing abundance (D. Perez-Salicrup and D. Lawrence, unpublished data).

logging, including those subsequently cleared for agriculture. Therefore, mature stands in our study represent forests in a pre-cultivation state, which may have been logged, but have not been used for agriculture in recent history. The sites were chosen due to their similarity in both ecological and cultivation history based on interviews with ejido members (P. Klepeis and C. Vance, personal communication). When possible, sites cultivated by the same family, but of different successional age were included to reduce management-induced and edaphic variation between sites.

\section{Field sampling}

Aboveground forest biomass in the SYPR was estimated using tree height, diameter at breast height (dbh, $1.4 \mathrm{~m}$ above the ground), and wood density according to existing allometric equations for tropical dry forest (Table 4; Crow 1978, Brown et al. 1989, Castellanos et al. 1991, Martinez-Yrizar et al. 1992, Gerwing and Lopes Farias 2000). Although many ecological and forest inventory studies in the tropics measure trees of different dbh classes, few studies have considered the contribution of stems $<5 \mathrm{~cm}$ dbh to total forest biomass. Due to the fact that small stems are the most important component of TAG forest biomass in young secondary forests, and to better understand their contribution to mature forest biomass, we included stems as small as $1 \mathrm{~cm}$ dbh in our study.

Within each of the $36500-\mathrm{m}^{2}$ circular plots, trees in three diameter classes $(1.0-4.9 \mathrm{~cm}, 5.0-9.9 \mathrm{~cm}$, and $\geq 10.0 \mathrm{~cm}$ ) were measured for $\mathrm{dbh}$. The $\mathrm{dbh}$ of all trees $\geq 10.0 \mathrm{~cm}$ dbh was measured within the 500 $\mathrm{m}^{2}$ plot. For measurement of trees $5-9.9 \mathrm{~cm} \mathrm{dbh}$, a $100-\mathrm{m}^{2}$ circular plot was established concentrically within each $500-\mathrm{m}^{2}$ plot. Three $10-\mathrm{m}^{2}$ circular plots were established directly outside the $100-\mathrm{m}^{2}$ plot to measure shrubs and saplings $1-4.9 \mathrm{~cm} \mathrm{dbh}$. For stems that were $<1.4 \mathrm{~m}$ tall, diameter was measured at a height of $1.05 \mathrm{~m}$.

Over all 36 sites combined, we measured 2940 trees for $\mathrm{dbh}$. To generate dbh-height relationships for later use in scaling up these diameter measurements to estimated tree heights, we measured an additional 1395 trees for both dbh and height. At each of 13 systematically arrayed sampling points within each $500-\mathrm{m}^{2}$ plot, the nearest tree from within each dbh size class was measured for both dbh and height using a clinometer or by direct measurement. If few or no trees were present in a certain dbh class, as occasionally occurred in the younger forests with no large trees, height and 
TABLE 4. Equations used to calculate tree height and aboveground biomass at sampling sites in the Southern Yucatan Peninsular Region (SYPR), Mexico.

\begin{tabular}{|c|c|c|c|}
\hline Parameter & Equation & $R^{2}$ & Source \\
\hline \multicolumn{4}{|l|}{ Height of trees } \\
\hline Secondary $(n=825)$ & $\begin{array}{c}\ln (\mathrm{ht})=0.99337+ \\
0.42681 \ln (\mathrm{dbh})\end{array}$ & 0.50 & this study \\
\hline Mature $(n=222)$ & $\begin{array}{l}\ln (\mathrm{ht})=0.93687+ \\
0.55204 \ln (\mathrm{dbh})\end{array}$ & 0.74 & this study \\
\hline Tree biomass & $\begin{array}{l}\log _{10}(\text { mass })=-0.7590+ \\
0.9011 \log _{10}(\text { BA })+ \\
0.5715 \log _{10}(\text { WSG })+ \\
0.5654 \log _{10}(\mathrm{ht})\end{array}$ & 0.96 & Martinez-Yrizar et al. (1992) \\
\hline Liana biomass & $\begin{array}{l}\log _{10}(\operatorname{mass})=0.07+ \\
2.17 \log _{10}(\mathrm{dbh})\end{array}$ & 0.95 & Gerwing and Lopes Farias (2000) \\
\hline \multicolumn{4}{|l|}{ Palm biomass } \\
\hline$<3 \mathrm{~cm} \mathrm{dbh}$ & $\begin{array}{c}\log _{10}(\text { mass })=-0.7590+ \\
0.9011 \log _{10}(\text { BA })+ \\
0.5715 \log _{10}(\text { WSG })+ \\
0.5654 \log _{10}(\mathrm{ht})\end{array}$ & 0.95 & Martinez-Yrizar et al. (1992) \\
\hline$\geq 3 \mathrm{~cm} \mathrm{dbh}$ & $\begin{array}{c}\ln (\text { mass })=3.6272+ \\
0.5768 \ln \left(\mathrm{dbh}^{2} \mathrm{ht}\right)\end{array}$ & 0.73 & Hughes et al. (2000) \\
\hline
\end{tabular}

dbh were measured for the nearest tree of the next smallest size class. This data set contained 1395 trees over all 36 sites, ensuring a large randomly sampled population of trees and tree heights within the study region and at each site.

\section{Estimation of forest biomass}

The data set of matched height and dbh was used to generate predictive relationships relating tree height to dbh in our sites. All data were first natural-log transformed to conform to assumptions of normality and homogeneity of variance (Sokal and Rohlf 1995, Cody and Smith 1997). A randomly selected quarter of the data (348 data points) was reserved for verifying the dbh-height model; the remaining three-quarters of the data set (1047 data points) was used to develop two regression equations, one each for mature and secondary forests (Table 4). Independent regression relationships between dbh and tree height for each region and each age class did not improve model fit. More importantly, the independent regressions were not significantly different based on tests for homogeneity of slopes (Freese 1967, Sokal and Rohlf 1995). However, we did find a significant difference between regressions for mature and secondary forests. For this reason, we employed only mature and secondary dbh-to-height regressions. These equations were used to convert the 2940 natural-log transformed tree dbh measurements to estimated height per tree (Table 4).

In order to validate the regressions relating tree $\mathrm{dbh}$ to height, predicted heights were generated for the 348 reserved data points for which actual tree height had been measured in the field. A paired $t$ test comparing actual vs. predicted heights for all 348 data points showed a significant difference $(P<0.01)$ between the pairs of values. The average true height of the 348 measured trees was $6.09 \mathrm{~m}$, compared to the average predicted height of $5.73 \mathrm{~m}$. Thus, our model slightly underestimated tree heights by an average of $0.36 \mathrm{~m}$, or $6 \%$ of the mean. Overall, there was no bias in predicted heights with respect to region, age, or dbh. For example, of 71 predicted heights for mature forest trees, 36 heights were overestimated and 35 were underestimated, but there was neither a regional bias nor any bias in dbh. Comparisons of measured and predicted heights for secondary forests yielded a similar lack of bias. Therefore, we are confident that the predicted heights generated for the 2940 trees whose dbhs were measured in the field estimate natural variability at our study sites.

Weighted mean wood density values for secondary and mature forests in each region (Table 5) were estimated using species composition data collected at each site (D. Perez Salicrup and D. Lawrence, unpub-

TABLE 5. Estimated wood specific gravity (WSG; all values are $\mathrm{g} / \mathrm{cm}^{3}$ ) at sampling locations in the Southern Yucatan Peninsular Region (SYPR), Mexico.

\begin{tabular}{lccc}
\hline \hline Stand age & $\begin{array}{c}\text { E1 } \\
\text { Refugio }\end{array}$ & $\begin{array}{c}\text { Nicolas } \\
\text { Bravo }\end{array}$ & $\begin{array}{c}\text { Arroyo } \\
\text { Negro }\end{array}$ \\
\hline Secondary & 0.59 & 0.53 & 0.52 \\
Mature & 0.69 & 0.67 & 0.70 \\
\hline
\end{tabular}

Note: Weighted mean WSG for secondary and mature forests were estimated using species composition data (see Methods: Estimation of forest biomass). 
lished data) and wood density values taken from the literature (Barajas-Morales 1987, Simpson and Sagoe 1991, Reyes et al. 1992). For tree species with no reported density, we used the mean wood density of other trees in the corresponding region and age category (Table 5; Lugo and Murphy 1986, Brown et al. 1989, Cairns et al. 2000).

Aboveground biomass of our stands in the SYPR was estimated from existing equations for tropical forests of the Americas (Table 4). Because of the dearth of literature on secondary dry tropical forests and on dry tropical forests in general, we chose those most representative of our site conditions and locations. We used the multiple regression equation presented by Martinez-Yrizar et al. (1992) for the dry tropical forests of Chamela, Mexico. Although annual precipitation in Chamela is low compared with some of our study sites, the forests have similar species composition, forest structure, and litterfall and precipitation patterns (Lott et al. 1987, Martinez-Yrizar and Sarukhan 1990, Castellanos et al. 1991, Martinez-Yrizar et al. 1992).

Liana biomass was estimated from a multispecies equation developed in forests of variable stature in the eastern Amazon with similar annual precipitation patterns to those in our study region (Gerwing and Lopes Farias 2000). Palms $<3 \mathrm{~cm}$ dbh were considered tree seedlings of very low wood density. To estimate their biomass, the equation of Martinez-Yrizar et al. (1992) was employed with a wood density of 0.1 (Rich 1987). Biomass of palms $\geq 3 \mathrm{~cm}$ dbh was estimated from an equation developed for Astrocaryum mexicanum (Hughes et al. 1999, 2000), a member of the same family (Aracaceae) as palm species in the SYPR.

\section{Statistical analyses}

We used analysis of variance (ANOVA) to investigate trends in forest biomass along regional and successional gradients. To explore successional trends, the 36 study sites were grouped across all three regions into age classes that best represent their ecological similarity and take into account any uncertainty in exact forest age. These age classes (2-5 yr, 6-10 yr, 12-25 $\mathrm{yr}$, and mature forest) refer to stand age in January 1999. We used regression analyses to understand the ability of these forests to accumulate biomass during recovery (Brown and Lugo 1990, Hughes et al. 1999, Nelson et al. 1999). To estimate this recovery, we generated one linear regression for all secondary sites relating TAG biomass to age, and used this equation to estimate the minimum ages of the mature forests based on their biomass. We did not use three independent regressions based on region because these lines were not significantly different based on homogeneity of slopes models (Freese 1967, Sokal and Rohlf 1995). Because the range of both TAG biomass and age were much higher in the mature forests compared to the secondary forests, we could not legitimately calculate $95 \%$ confidence intervals for the estimates of mature forest age (Sokal and Rohlf 1995). However, by comparing the ages of our secondary sites to the estimated mature forest ages, we estimated the minimum time necessary for secondary sites to recover to mature forest biomass levels.

Since we determined TAG biomass using several components of forest biomass (trees, palms, and lianas), we also considered their relative contribution to overall forest structure. Additionally, we investigated regional and successional differences in tree height and basal area because we believed their dynamics might explain variability and overall trends in TAG biomass. We used simple ANOVA to investigate differences in basal area between regions and between age classes. To investigate trends in tree heights within a given dbh size class, our data set consisted of the 1395 trees for which tree heights were directly measured in nested plots in the field. We chose to compare regional and successional changes in height of measured trees within dbh size classes only, because our sampling method was designed to generate dbh-to-height relationships rather than to estimate overall forest height.

In our analysis of regional differences in height, we removed the influence of forest age, which covaried with tree height (Pearson correlation coefficient $r=$ 0.41). After testing for assumptions of ANOVA and homogeneity of slopes (Sokal and Rohlf 1995, Cody and Smith 1997), we proceeded with ANCOVA analysis on natural-log transformed height data to compare regions within a given dbh size class. Reported means for ANCOVA comparing tree height between regions are least-squares means, not simple arithmetic means, to account for the covariate (Sokal and Rohlf 1995).

We used ANOVA to investigate changes in height of measured trees among age classes within a given dbh size class, changes in stem density, and the contribution of stems of different dbh to biomass. Standard errors were computed in natural-log transformed values before being back-transformed to an arithmetic scale for display. All statistical analyses were carried out using SAS Version 8 (SAS Institute 1989). When necessary, data were natural-log transformed to conform to assumptions of ANOVA (Sokal and Rohlf 1995, Cody and Smith 1997).

\section{RESUlts \\ Estimates of forest biomass}

Total aboveground biomass in the SYPR, including trees, palms, and lianas, ranged from $10 \mathrm{Mg} / \mathrm{ha}$ in a 3yr-old forest to $163 \mathrm{Mg} / \mathrm{ha}$ in a mature site (Table 6). Over the successional gradient, biomass increased significantly with age, with similar trajectories of recovery among the three study regions (Figs. 2 and 3). TAG biomass tripled in the first $12-25 \mathrm{yr}$, and by this time, had acquired approximately half the biomass of mature forests (Figs. 2 and 3). Due to considerable variability in forest biomass within the three study regions, there were no significant differences in TAG biomass over 
TABLE 6. Basal area and total aboveground (TAG) biomass at study sites in the Southern Yucatan Peninsular Region (SYPR), Mexico.

\begin{tabular}{|c|c|c|c|c|c|c|c|}
\hline \multirow[b]{2}{*}{ Region } & \multirow[b]{2}{*}{ Site } & \multirow[b]{2}{*}{ Age } & \multirow{2}{*}{$\begin{array}{c}\text { Basal } \\
\text { area } \\
\left(\mathrm{m}^{2} / \mathrm{ha}\right)\end{array}$} & \multicolumn{4}{|c|}{ Biomass (Mg/ha) } \\
\hline & & & & Tree & Palm & Liana & Total \\
\hline \multirow[t]{13}{*}{ E1 Refugio } & Hermelindo & 2 & 9.3 & 22.36 & 0 & 0 & 22.36 \\
\hline & Juventino & 3 & 4.4 & 10.60 & 0 & 0 & 10.60 \\
\hline & Juan & 4 & 7.7 & 15.96 & 0.33 & 0 & 16.30 \\
\hline & Hermelindo & 5 & 7.2 & 17.48 & 0 & 0 & 17.48 \\
\hline & Rufino & 8 & 10.5 & 25.83 & 0 & 3.23 & 29.07 \\
\hline & Juan & 8 & 9.1 & 19.97 & 0.57 & 0 & 20.53 \\
\hline & Juventino & 10 & 15.9 & 39.67 & 0 & 0 & 39.67 \\
\hline & Juan & 12 & 20.7 & 43.81 & 0.87 & 0.87 & 45.56 \\
\hline & Hermelindo & 12 & 18.3 & 44.45 & 0 & 10.25 & 54.70 \\
\hline & Juventino & 12 & 24.6 & 60.98 & 0 & 0 & 60.98 \\
\hline & Victor & mature & 36.5 & 118.58 & 0 & 1.76 & 120.34 \\
\hline & Camino Pr. & mature & 37.7 & 117.64 & 0 & 20.90 & 138.54 \\
\hline & Roberto & mature & 37.7 & 123.20 & 0 & 0.48 & 123.68 \\
\hline \multirow[t]{13}{*}{ Nicolas Bravo } & Agustin & 3 & 17.5 & 15.69 & 2.47 & 0 & 18.17 \\
\hline & Pedro & 5 & 14.6 & 31.20 & 0.12 & 3.12 & 34.44 \\
\hline & Enrique & 5 & 28.0 & 64.06 & 0 & 0 & 64.06 \\
\hline & Agustin & 6 & 9.2 & 19.91 & 0.35 & 0.48 & 20.74 \\
\hline & Benito & 8 & 10.8 & 24.87 & 0 & 0 & 24.87 \\
\hline & Pedro & 16 & 19.2 & 38.15 & 0.38 & 11.49 & 50.02 \\
\hline & Benito & 18 & 20.6 & 49.72 & 0 & 0.69 & 50.41 \\
\hline & Pedro & 24 & 34.3 & 97.57 & 0 & 0 & 97.57 \\
\hline & Agustin & 25 & 26.5 & 78.62 & 0.29 & 15.29 & 94.20 \\
\hline & Enrique & 25 & 29.2 & 60.27 & 0.19 & 0 & 60.46 \\
\hline & NB 1 & mature & 43.8 & 131.39 & 0.95 & 30.96 & 163.30 \\
\hline & NB2 & mature & 39.1 & 125.77 & 0.45 & 6.88 & 133.11 \\
\hline & Calakmulita & mature & 45.0 & 147.79 & 0 & 10.09 & 157.88 \\
\hline \multirow[t]{10}{*}{ Arroyo Negro } & Antonio & 4 & 5.9 & 11.81 & 0.53 & 0 & 12.34 \\
\hline & Fermin & 5 & 13.8 & 31.60 & 0 & 0 & 31.60 \\
\hline & Gilberto & 5 & 12.8 & 24.97 & 0.19 & 0 & 25.17 \\
\hline & Gilberto & 7 & 5.1 & 11.89 & 0 & 0 & 11.89 \\
\hline & Antonio & 8 & 18.8 & 29.08 & 0.58 & 32.88 & 62.55 \\
\hline & Fermin & 9 & 10.2 & 19.22 & 1.21 & 0 & 20.42 \\
\hline & Fermin & 15 & 24.4 & 32.26 & 2.87 & 1.06 & 36.19 \\
\hline & Antonio & 18 & 64.2 & 19.29 & 8.30 & 0 & 27.59 \\
\hline & Antonio & mature & 38.0 & 136.31 & 0 & 0 & 136.31 \\
\hline & Jose & mature & 30.9 & 106.90 & 0 & 11.26 & 118.16 \\
\hline
\end{tabular}

the regional precipitation gradient, or between regions within a given age class (Fig. 2).

\section{Biomass recovery following shifting cultivation}

Assuming that biomass accumulation follows a linear trend, we estimate that recovery to pre-cultivation levels requires a minimum of 40-60 yr and a maximum of $95 \mathrm{yr}$. Regression analysis indicates that secondary forest biomass is related to age based on the relationship: TAG biomass $(\mathrm{Mg} / \mathrm{ha})=11.431+2.615 \times$ age $\left(R^{2}=0.57, n=28, P<0.0001\right.$; Fig. 3). Using this regression line, estimated minimum ages for the mature
FIG. 2. Total aboveground (TAG) biomass by age class within each sampling region and in the Southern Yucatan Peninsular Region (SYPR) overall. Results are of four ANOVAs (all $P<0.001$ ) comparing TAG by age class within each region and in the SYPR overall. Bars depict means $\pm 1 \mathrm{SE}$, and those with different letters within each of the regions are significantly different at $\alpha=0.05$ (Tukey post hoc test).

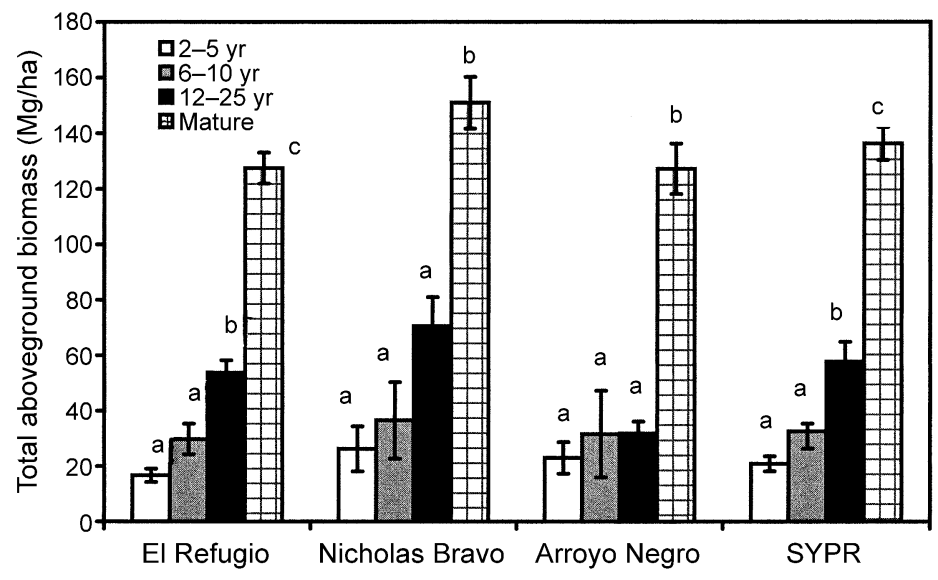




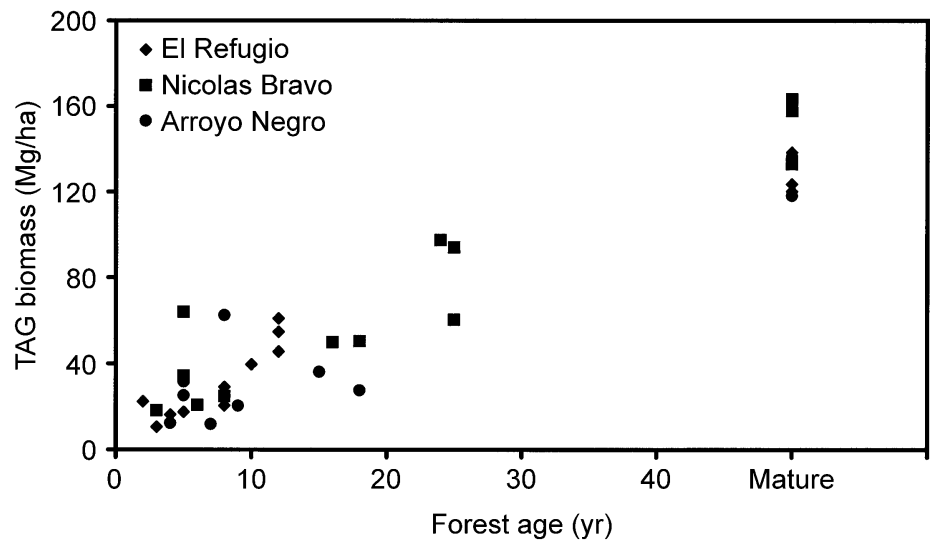

FIG. 3. Total aboveground (TAG) biomass as a function of forest age in the Southern Yucatan Peninsular Region (SYPR). Symbols represent samples from three different study regions along the precipitation gradient.

study sites in the SYPR range from 41 to $58 \mathrm{yr}$ (Table $7)$. Our analysis suggests that the annual biomass increment is $2.3-3.4 \mathrm{Mg} \cdot \mathrm{ha}^{-1} \cdot \mathrm{yr}^{-1}$ in secondary forests aged 2-25 yr. If the rate of biomass accrual declines in older secondary forests, as canopy closure occurs, then the time to reach mature forest levels would be $>60$ yr. If we assume that canopy closure occurs 12 $25 \mathrm{yr}$ following abandonment, resulting in a $50 \%$ decline in biomass increment thereafter, it may take as long as 55-95 yr to reach mature forest levels.

\section{Basal area and tree height}

Total basal area in mature forests ranged from 30.9 to $45.0 \mathrm{~m}^{2} /$ ha (Table 6 ). In secondary forests, total basal area ranged from 5.9 to $34.3 \mathrm{~m}^{2} / \mathrm{ha}$, with one anomalously high value of $64.2 \mathrm{~m}^{2} / \mathrm{ha}$ due to mature palms at that site. Basal area did not differ among regions in any age class except the 2-5-yr-old age class. In these young forests, the mean basal area of El Refugio was less than that of Nicolas Bravo (ANOVA, $P=0.037$ ).

TABLE 7. Minimum estimated age of mature forests at the sampling locations in the Southern Yucatan Peninsular Region (SYPR), Mexico.

\begin{tabular}{lcc}
\hline \hline Region and Site & $\begin{array}{c}\text { TAG biomass } \\
(\mathrm{Mg} / \mathrm{ha})\end{array}$ & $\begin{array}{c}\text { Estimated } \\
\text { age }(\mathrm{yr}) \dagger\end{array}$ \\
\hline E1 Refugio & 120.34 & 42 \\
$\quad$ Victor & 138.54 & 49 \\
Camino Pr. & 123.68 & 43 \\
$\quad$ Roberto & & \\
Nicolas Bravo & 163.30 & 58 \\
NB1 & 133.11 & 47 \\
NB2 & 157.88 & 56 \\
Calakmulita & & \\
Arroyo Negro & 136.31 & 48 \\
$\quad$ Antonio & 118.16 & 41 \\
Jose & 136.42 & 48 \\
Mean estimate for mature forests & &
\end{tabular}

$\dagger$ Ages are based on the regression equation total aboveground $(\mathrm{TAG})$ biomass $(\mathrm{Mg} / \mathrm{ha})=11.431+2.615 \times$ age developed from biomass of secondary forest sites in the SYPR.
Total basal area in the study sites increased with age (ANOVA, $P<0.001$; Fig. 4). However, this successional change in basal area was driven primarily by differences between age classes in the two drier regions (ANOVA, ER: $P<0.0001$; NB: $P=0.003$ ). Differences in basal area between age classes in the wettest region were marginally significant (ANOVA, AN: $P=$ 0.062 ).

There were no regional differences between mean heights of measured trees in the two larger size classes; least-squares mean heights for these size classes were $6.4 \mathrm{~m}$ and $9.3 \mathrm{~m}$, respectively. Within the smallest $\mathrm{dbh}$ class, 1-4.9 cm dbh, measured stems in Nicolas Bravo were significantly taller than in El Refugio or Arroyo Negro (4.0 m vs. $3.7 \mathrm{~m}$ and $3.6 \mathrm{~m}$, respectively; ANCOVA, regional effect, $P<0.0003)$. As expected, the mean height of measured trees within the two larger size classes increased with increasing forest age (Fig. $5)$. However, in the smallest class, measured trees in the 12-25-yr-old age class were the tallest, rather than those in the mature age class (Fig. 5).

\section{Trends in forest structure}

In spite of the fact that forest biomass increased consistently with age (Figs. 2 and 3), the number of stems

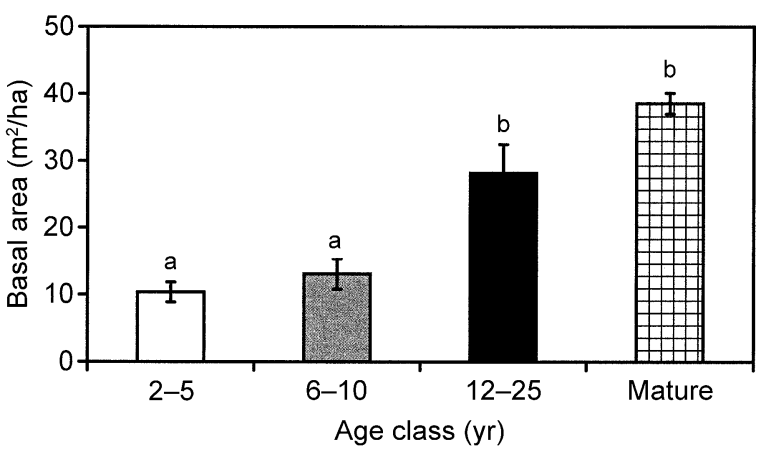

FIG. 4. Total basal area of study sites by age class. Basal area includes palms, lianas, and trees $>1 \mathrm{~cm}$ dbh (ANOVA, $P<0.0001)$. Bars are means $\pm 1 \mathrm{SE}$, and those with different letters are significantly different at $\alpha=0.05$ (Tukey post hoc test). 
FIG. 5. Mean height of measured trees $(n=$ 1395) by dbh size class. Bars are means \pm 1 SE. Results are of ANOVAs (all $P<0.0001$ ) within each size class, comparing tree heights as a function of forest age. Within each size class, bars with different letters are significantly different at $\alpha=0.05$ (Tukey post hoc test).

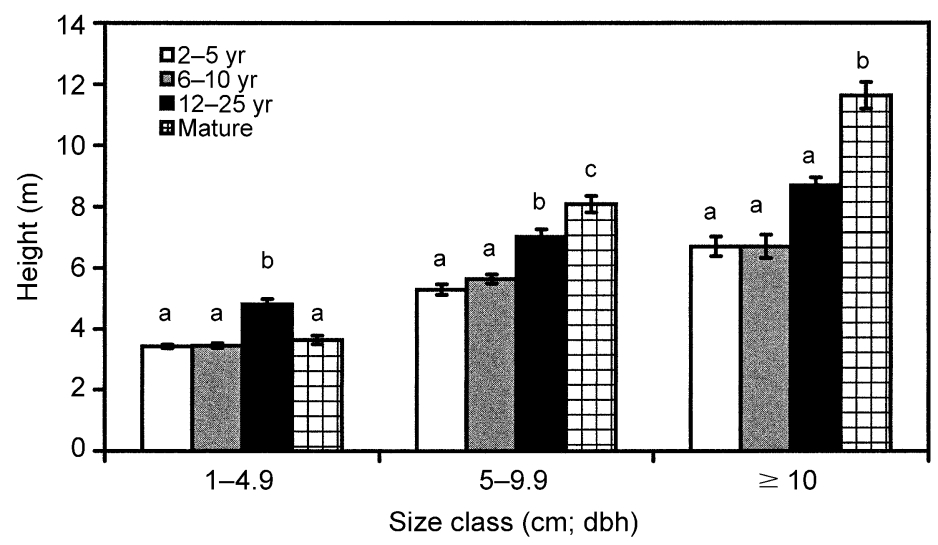

in our study sites was quite variable within a given age class or region (Fig. 6). A two-way ANOVA $(P=0.11)$ comparing stem density of the three regions and four age classes indicated a trend of declining stem density with age (age class effect, $P=0.07$ ), but no significant regional differences (region effect, $P=0.69$ ). In the youngest age class, density ranged from 13000 to 33000 stems/ha, while mature sites had an average of 12800 stems/ha. In Arroyo Negro, the number of stems quickly declined to pre-cultivation forest levels. A similar pattern occurred in Nicolas Bravo, with stem density reduced substantially during succession. In contrast, the reduction in stem density was much weaker in the driest region, El Refugio (Fig. 6). The density of trees $\geq 10 \mathrm{~cm} \mathrm{dbh}$ in the mature forests of Arroyo Negro was $\sim 130$ trees/ha, slightly less than half that found in El Refugio and Nicolas Bravo. Although total tree density was lower in the south, the presence of very large trees increased along the precipitation gradient. In the mature forests of Arroyo Negro, 39\% of trees $\geq 10 \mathrm{~cm}$ dbh were actually $\geq 20 \mathrm{~cm} \mathrm{dbh}$, compared to $35 \%$ in Nicolas Bravo and only $17 \%$ in El Refugio.

The contribution of stems of different size classes to biomass displayed little regional variability but did vary over the successional gradient. In sites $2-5 \mathrm{yr}$ old, stems $1-4.9 \mathrm{~cm}$ dbh made up almost $80 \%$ of total forest biomass (Fig. 7). In mature sites, stems $\geq 10 \mathrm{~cm} \mathrm{dbh}$ made up about $70 \%$ of biomass, while stems $1-4.9 \mathrm{~cm}$ dbh contributed $15 \%$ of total biomass. Trees accounted for about half of this small stem biomass, and palms and lianas contributed the remaining portion. Stems in our middle size class, 5-9.9 $\mathrm{cm}$ dbh, made up a larger component of forest biomass in 6-10-yr-old stands compared to $12-25-y r-o l d ~ s t a n d s$, indicating the passage of small trees through the dbh sampling classes into the largest class (Fig. 7).

\section{DISCUSSION}

\section{Recovery of forest biomass}

Total aboveground biomass increased rapidly during succession (Figs. 2 and 3), and this plays a large role in the ability of secondary tropical forests to accumulate and store carbon (Brown and Lugo 1990). Within the study area, there was a nonsignificant trend toward increased biomass with increasing precipitation to the south, although the biomass of mature forests in Arroyo Negro was lower than expected (Fig. 2). Differences in biomass between the regions were smaller than expected given the range of precipitation observed ( $~ 900-1400 \mathrm{~mm} / \mathrm{yr}$ ). Considering that the precipitation gradient over which our study sites are located
FIG. 6. Total number of stems per hectare, by age class and by region. Mean number of stems (trees, palms, and lianas) per hectare were extrapolated from stems $>1 \mathrm{~cm}$ dbh measured in each $500-\mathrm{m}^{2}$ sampling plot. A two-way ANOVA $(P=0.11)$ indicates a strong age-class effect $(P=0.07)$, but no regional differences $(P=0.69)$. Bars are means \pm 1 SE.

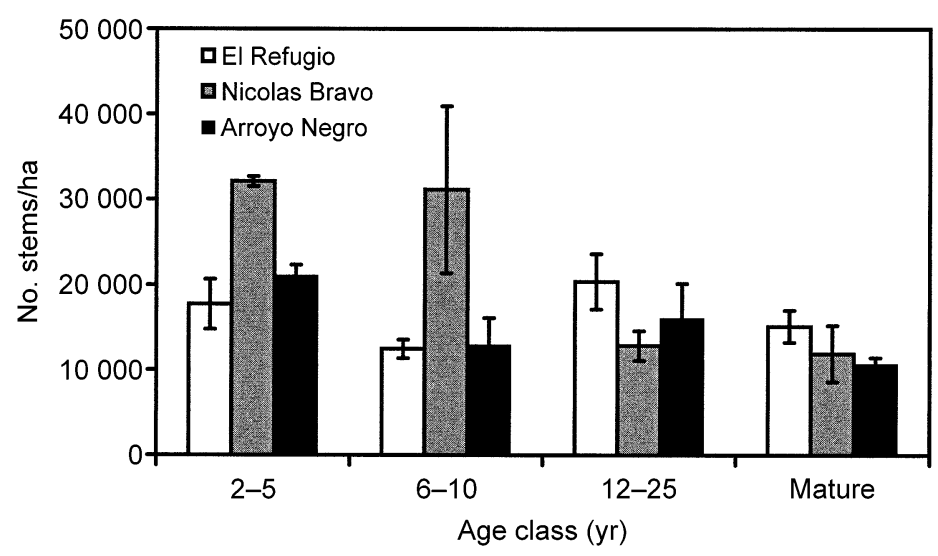




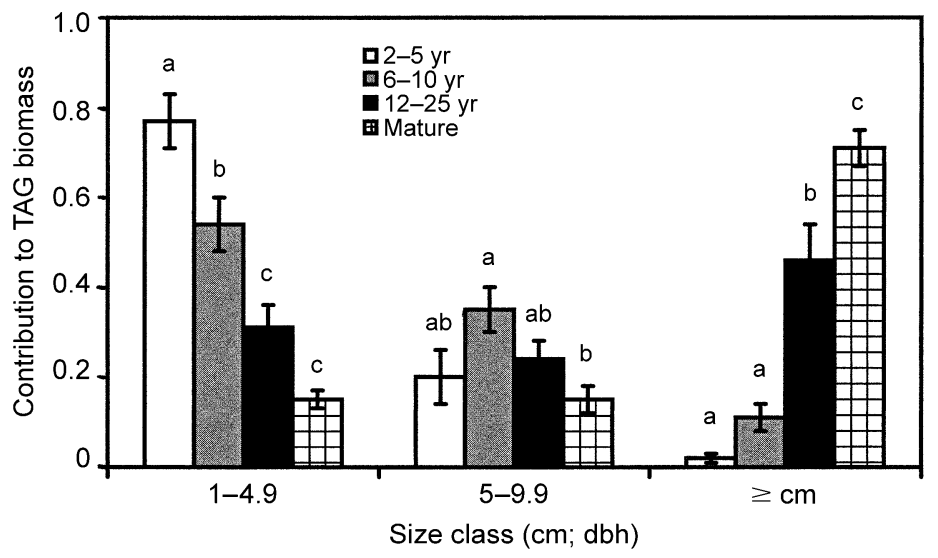

FIG. 7. Relative contribution of stems of different dbh size classes to total aboveground (TAG) biomass. Results are of three ANOVAs (all $P<0.05$ ) comparing the contribution of a given size class to biomass, in forests of different ages. Bars are means $\pm 1 \mathrm{SE}$, and those with different letters within each of the three dbh classes are significantly different at $\alpha=$ 0.05 (Tukey post hoc test). encompasses about half the precipitation gradient in which dry tropical forests of the Americas are found ( 700-1500 mm/yr; Murphy and Lugo 1995), larger regional differences in biomass might be expected. The nonsignificance may in part be due to the variability within a given region. Thus, human disturbance, including cultivation history and logging activity, may be important factors constraining recovery of forest biomass in the SYPR.

Regression equations relating secondary forest biomass to age within each of the three regions were not significantly different, suggesting that despite slight differences in regional disturbance history and precipitation, the overall trajectories of recovery of secondary forest biomass in the SYPR are very similar. By comparing mature forest biomass to the trajectory of biomass recovery in secondary forests, we estimated that secondary forests return to pre-cultivation forest biomass within 55-95 yr. These estimates overlap with Brown and Lugo's $(1982,1990)$ estimate of an $\sim 50$-yr recovery time for dry tropical forests, but our analysis suggests the potential for a slower recovery.

As noted previously, the mature forests of study were logged for mahogany and Spanish cedar, removing the largest stems. Domination by these or other large trees might take an additional 10-25 yr, assuming an ultimate density of 6 trees/ha with diameters of $100 \mathrm{~cm}$ (see Rodriguez Caballero 1944, Snook 1998). Thus, we estimate that forests similar in total aboveground biomass to those observed in the 19th century (before logging) might be reached $65-120 \mathrm{yr}$ after agricultural abandonment. This estimate agrees with estimates of recovery time in the wet tropical forests of Los Tuxtlas, Mexico, where forest recovery may take $70 \mathrm{yr}$ or more (Hughes et al. 1999).

Estimates of mature forest TAG biomass, at 118$163 \mathrm{Mg} / \mathrm{ha}$, are higher than reported values of $85-90$ $\mathrm{Mg} / \mathrm{ha}$ for other American tropical dry forests (Murphy and Lugo 1986b, Martinez-Yrizar et al. 1992), but our study area receives greater annual precipitation than these areas (900-1400 $\mathrm{mm}$ vs. $700-860 \mathrm{~mm}$ ). Like- wise, the SYPR biomass estimates are much lower than the $403 \mathrm{Mg} / \mathrm{ha}$ reported for a humid tropical forest in a nearby region of Mexico receiving $4700 \mathrm{~mm} / \mathrm{yr}$ (Hughes et al. 2000). However, on a global scale, our estimates are within the range of previously reported values for both secondary and dry tropical forests (Brown and Lugo 1982, 1990, Murphy and Lugo 1986a).

Several aspects of forest structure contribute to the variable biomass levels within each study region and over the successional gradient (Table 6). The number of stems in each plot was highly variable in both young and mature stands (Fig. 6). Additionally, although mature forest biomass levels were not achieved within 25 $\mathrm{yr}$, the number of stems in Nicolas Bravo, and especially in Arroyo Negro, declined sharply during succession and reached stem densities similar to mature forest within $\sim 15 \mathrm{yr}$ (Fig. 6). As expected, the contribution of small stems $1-4.9 \mathrm{~cm}$ dbh to TAG biomass decreased during succession, while large stems played an increasingly important role (Fig. 7), but the contribution of small stems to mature forest biomass should not ignored. In our study sites, $15 \%$ of TAG biomass in mature forests was comprised of trees, palms, and lianas of 1-4.9 cm dbh. Stems 1-9.9 cm dbh comprised $30 \%$ of mature forest biomass. Basal area increased steadily with successional age (Fig. 4) and only varied between the three study regions in the youngest forests (Table 6). However, within our dbh sampling classes, tree heights increased dramatically with forest age (Fig. 5 ), and these successional changes in tree height were an important driver of biomass at the sampling sites. Despite the tendency to rely on diameter measures alone based on experience in mature forests, including measures of height is essential to accurately quantify biomass in secondary forests.

The presence of palms and lianas in some, but not all, of the study sites contributed to the variation in TAG biomass at both secondary and mature sites (Table 6). For example, the palm biomass in an 18-yr-old study site in Arroyo Negro dominated basal area in that site, 
causing tree biomass to be much lower than expected for a site of that age. Due to their unusual growth form, high basal area, and low biomass, palms can have a significant impact on surrounding vegetation with implications for forest structure. According to local informants, palms do not necessarily succumb to fire during the burning stage of shifting agriculture (and see Tomlinson 1979). In addition, palms are also preserved in the forest environment for their cultural and economic uses (Prance et al. 1987). While palms are a component of TAG biomass at some of our sites, they make estimates of biomass recovery difficult in sites where they are dominant. However, because palms are a legitimate, albeit variable component of aboveground biomass in many secondary tropical forests, including disturbed sites, we have included them in our TAG biomass estimates.

Liana biomass was highly variable, but is also an important component of TAG biomass at many of our sites (Table 6). Although few studies of tropical forests incorporate lianas into biomass estimates, their adaptation to high-light environments makes them well suited for secondary and disturbed areas (Dewalt et al. 2000). Due to their ability to use other plants for structural support, lianas can have up to five times the leaf mass of trees of the same dbh (Putz 1983, Gerwing and Lopes Farias 2000). Therefore, their measurement is critical for the establishment of accurate biomass estimates in secondary and mature tropical forests where they are present (Dewalt et al. 2000, Gerwing and Lopes Farias 2000). Additionally, the presence of lianas in a few older secondary and mature sites may signal previous disturbances that opened the canopy and allowed lianas to proliferate (Putz 1983, Dewalt et al. 2000).

In light of the generally accepted theory that forest biomass in the tropics increases with increasing precipitation (Brown and Lugo 1982, Murphy and Lugo $1986 a$ ), mean levels in mature forests of Arroyo Negro seem low (Table 6). Despite the lower number of stems in these sites, the total basal area and biomass in those stands is similar to other mature stands sampled (Table 6). In the mature Arroyo Negro sites, fewer trees with larger basal area (see Results) make up a greater proportion of TAG biomass. We also believe that the mature forests of Arroyo Negro experienced heavier and more recent selective logging than the mature forests of El Refugio and Nicolas Bravo, despite intensive logging at those sites 40-50 yr ago (Klepeis 2000). Therefore, the recent harvesting of large trees in Arroyo Negro may be a large factor in the lower forest biomass estimated there (Table 6; Turner et al. 2001). If this is the case, biomass in mature forests of Nicolas Bravo may be more representative of undisturbed mature dry tropical forest in the Southern Yucatan.

Another potential explanation for the lower biomass in Arroyo Negro mature sites is that they are responding to higher annual precipitation with greater foliar pro- duction rather than increased woody biomass (Brown and Lugo 1982). In fact, preliminary analysis of litterfall data from mature forests does indicate higher production in Arroyo Negro than in the other study regions (Lawrence and Foster 2002). A final reason for the low biomass values in the southern region is that there were only two mature forest sites in Arroyo Negro, compared to three in each of the other study regions, and one of these sites had a markedly low number of stems and basal area. A power test suggests that nine plots would allow an estimate of mature forest biomass for the entire study area within $10 \%$ of the mean at a 95\% confidence level (Steel and Torrie 1980). Yet, to eliminate uncertainty in our assessment of interregional differences (regional estimates with similar confidence levels), we would need 11 plots in ER, 21 in NB, and 164 in AN. The variability we observed is a very real property of disturbed landscapes, not simply a statistical or sampling problem. As shown in Mexican wet tropical forest, prior land-use history may have a profound effect on biomass recovery (Hughes et al. 1999). This study suggests it can have a greater effect than the regional environmental gradient in precipitation.

\section{Sources of bias}

Several sources of error and bias, common to many biomass estimation studies, exist in the data presented. First, land-use history is variable. Within our 36 study sites, which were chosen for uniformity of land-use history, the number of previous fallow cycles and the number of years in maize varies somewhat (Table 2). Other uncertainty lies in our knowledge of potential thinning and harvesting activity. Although all the secondary forest sites were used for maize agriculture, sporadic and undocumented logging activity, especially in Arroyo Negro, may be an unquantified factor affecting TAG biomass and recovery in the SYPR. Finally, although the inferential approach of studying succession using forests of different age is commonly used (see review in Brown and Lugo 1990), natural variability between sites that may influence recovery is unavoidable (Aweto 1981, Lugo 1992).

Estimates of tree height represent another potential source of bias. Our model for estimating tree heights based on field measurements underestimated heights by $0.36 \mathrm{~m}$ below the mean height of $6.09 \mathrm{~m}$. This may be within the expected error associated with using a clinometer to measure trees within the range of heights observed. Regardless, we are confident that our regression equations predicting tree height from dbh are adequate for two reasons. First, they are derived from a large sample of trees measured in the field at our sites, taking into account the species composition and diversity of the sites. Second, the differences between field-measured and predicted heights for the same trees do not show systematic bias towards any region, age class, or ranges of $\mathrm{dbh}$. 
Estimates of wood density for secondary and mature sites may also introduce bias into our calculations of forest biomass. Because reported wood densities for tropical tree species are largely restricted to late-successional and commercially important species (Brown et al. 1989, Reyes et al. 1992), substitution of an average wood density for the American tropics is common (Brown et al. 1989, Hughes et al. 1999, Cairns et al. 2000). The range of our wood density values for secondary and mature sites in the three sampling regions (Table 5) corresponds well to the reported mean wood density of 0.60 for tropical species in the Americas (Brown 1997).

A final source of error in our estimates lies in the applicability of the allometric equations themselves to secondary forests of the SYPR. To the best of our knowledge, we chose equations to calculate biomass of trees, palms, and lianas that were the most applicable to our study region. Only two published, commonly used equations for estimating biomass in dry tropical forest exist to date, one of which was developed for sites in India (Brown 1997). The equation we used was developed in a region of western Mexico that receives annual rainfall comparable to levels at the lower end of the precipitation gradient in the SYPR (MartinezYrizar et al. 1992). However, it is more suitable than the equation developed for Indian forests because important parameters such as species composition and rainfall patterns are similar to those in the SYPR. Although the equation was developed for mature forests, the range of dbh $(3-30 \mathrm{~cm})$ that it encompasses is comparable to those in both secondary and mature forests (Martinez-Yrizar et al. 1992, Brown 1997). Therefore, this choice addresses one of the more troublesome and common uncertainties in biomass estimation, the application of an equation outside the range of $\mathrm{dbh}$ for which it was developed (Nelson et al. 1999).

\section{Conclusion}

We estimated that secondary forests in the dry tropics of the Southern Yucatan recover within 55-95 yr to pre-cultivation biomass. Recovery to level associated with the unlogged forests of the late 19th century might take 65-120 yr. TAG biomass is driven largely by successional age and is only moderately variable over the regional precipitation gradient. Increased sampling effort would help to determine the influence of precipitation on forest recovery, and additional studies are underway (D. Perez-Salicrup, unpublished data). Observed variability is due in part to differences in basal area, number of stems, tree height, and species composition. Additionally, other parameters, such as soil fertility and land-use history, may be important factors driving variability in biomass and should be investigated further. Furthermore, trees, palms, and lianas $1-5 \mathrm{~cm}$ dbh make an important contribution to forest biomass not only in young successional stands, but also in mature forests. In our study, these small stems made up $15 \%$ of TAG biomass in mature forests. Although most previous estimates of biomass in the tropics do not account for stems of this range, we suggest that their inclusion in future studies will allow for more accurate estimates of both secondary and mature forest biomass. The rapid recovery of biomass in these forests has important implications for our understanding of their ecosystem dynamics, in addition to enhancing our ability to manage them prudently. Despite natural local and regional variability, as well as the difficulties associated with quantifying land-use history and human disturbance, accurate estimates of tropical secondary forest biomass are essential to understanding the successional dynamics of these forests as well as their role in the global carbon cycle.

\section{ACKNOWLEDGMENTS}

The research in this article was funded primarily by NSF (LTER-Harvard Forest and the REU program), the A.W. Mellon Foundation, and the University of Virginia. This work was conducted under the auspices of the Southern Yucatan Peninsular Region project with core sponsorship from NASA's LCLUC (Land-Cover and Land-Use Change) program (NAG 56406) and the Center for Integrated Studies on Global Change, Carnegie Mellon University (CIS-CMU; NSF-SBR 95-21914). SYPR is a collaborative project of El Colegio de la Frontera Sur (ECOSUR), Harvard University, the George Perkins Marsh Institute of Clark University, the University of Virginia, and Carnegie Mellon University. Special thanks to Diego Perez-Salicrup for species composition data and tree diameter data for some of our study sites. We are especially grateful to Fausto Bolom-Ton, Pedro Macario Mendoza, Juan Mendez Diaz, Jessica Sisco, Heidi Wasson, and to the farmers of the SYPR, who made this work possible.

\section{Literature Cited}

Arnason, J. T., and J. D. H. Lambert. 1982. Nitrogen cycling in the seasonally dry forest zone of Belize, Central America. Plant and Soil 67:333-342.

Aweto, A. O. 1981. Secondary succession and soil fertility restoration in south-western Nigeria: II. Soil fertility restoration. Journal of Ecology 69:609-614.

Barajas-Morales, J. 1987. Wood specific gravity in species from two tropical forests in Mexico. IAWA Bulletin 8:143148.

Boose, E. R., D. R. Foster, and M. Fluet. 1994. Hurricane impacts to tropical and temperate forest landscapes. Ecological Monographs 64:369-400.

Brown, S. 1997. Estimating biomass and biomass change of tropical forests. A primer. FAO Forestry Paper 134. Food and Agriculture Organization of the United Nations, Rome, Italy.

Brown, S., A. J. R. Gillespie, and A. E. Lugo. 1989. Biomass estimation methods for tropical forests with applications to forest inventory data. Forest Science 35:881-902.

Brown, S., and A. E. Lugo. 1982. The storage and production of organic matter in tropical forests and their role in the global carbon cycle. Biotropica 14:161-187.

Brown, S., and A. E. Lugo. 1990. Tropical secondary forests. Journal of Tropical Ecology 6:1-32.

Buschbacher, R., C. Uhl, and E. A. S. Serrao. 1988. Abandoned pastures in eastern Amazonia. II: nutrient stocks in the soil and vegetation. Journal of Ecology 76:682-699.

Cairns, M. A., P. K. Haggerty, R. Alvarez, B. H. J. DeJong, and I. Olmsted. 2000. Tropical Mexico's recent land-use change: a region's contribution to the global carbon cycle. Ecological Applications 10:1426-1441. 
Castellanos, J., M. Maass, and J. Kummerow. 1991. Root biomass of a dry deciduous tropical forest in Mexico. Plant and Soil 131:225-228.

Cody, R. P., and J. K. Smith. 1997. Applied statistics and the SAS programming language. Fourth edition. Prentice Hall, Upper Saddle River, New Jersey, USA.

Crow, T. R. 1978. Common regressions to estimate tree biomass in tropical stands. Forest Science 24:110-114.

Dewalt, S. J., S. A. Schnitzer, and J. S. Denslow. 2000. Density and diversity of lianas along a chronosequence in a central Panamanian lowland forest. Journal of Tropical Ecology 16:1-19.

Ewel, J. J. 1980. Tropical succession: manifold routes to maturity. Biotropica 12:2-7.

Freese, F. 1967. Elementary statistical methods for foresters. USDA Forest Service Handbook 317. Washington, D.C., USA.

Gerwing, J. H., and D. Lopes Farias. 2000. Integrating liana abundance and forest stature into an estimate of total aboveground biomass for an eastern Amazonian forest. Journal of Tropical Ecology 16:237-335.

Harmon, M. E., D. F. Whigham, J. Sexton, and I. Olmstead. 1995. Decomposition and mass of woody detritus in the dry tropical forests of the northeastern Yucatan Peninsula, Mexico. Biotropica 27:305-316.

Hughes, R. F., J. B. Kauffman, and V. J. Jaramillo. 1999. Biomass, carbon, and nutrient dynamics of secondary forests in a humid tropical region of Mexico. Ecology 80: 1892-1907.

Hughes, R. F., J. B. Kauffman, and V. J. Jaramillo. 2000. Ecosystem-scale impacts of deforestation and land use in a humid tropical region of Mexico. Ecological Applications 10:515-527.

Kauffman, J. B., R. L. Sanford, Jr., D. L. Cummings, I. H. Salcedo, and E. V. S. B. Sampaio. 1993. Biomass and nutrient dynamics associated with slash fires in Neotropical dry forests. Ecology 74:140-151.

Klepeis, P. 2000. Deforesting the once deforested: land transformation in southeastern Mexico. Dissertation. Clark University, Worchester, Massachusetts, USA.

Lawrence, D., and D. R. Foster. 2002. Changes in forest biomass, litter dynamics and soils following shifting cultivation in southern Mexico: an overview. Interciencia 27(8):400-408.

Lott, E. J., S. H. Bullock, and J. A. Solis-Magallanes. 1987. Floristic diversity and structure of upland and arroyo forests of coastal Jalisco. Biotropica 19:228-235.

Lugo, A. E. 1992. Comparison of tropical tree plantations with secondary forests of similar age. Ecological Monographs 62:1-41.

Lugo, A. E., and P. G. Murphy. 1986. Nutrient dynamics of a Puerto Rican subtropical dry forest. Journal of Tropical Ecology 2:55-72.

Martinez-Yrizar, A., and J. Sarukhan. 1990. Litterfall patterns in a tropical deciduous forest in Mexico over a fiveyear period. Journal of Tropical Ecology 6:433-444.

Martinez-Yrizar, A., J. Sarukhan, A. Perez-Jimenez, E. Rincon, J. M. Maas, A. Solis-Magallanes, and L. Cervantes. 1992. Above-ground phytomass of a tropical deciduous forest on the coast of Jalisco, Mexico. Journal of Tropical Ecology 8:87-96.

Murphy, P. G., and A. E. Lugo. 1986a. Ecology of tropical dry forest. Annual Review of Ecology and Systematics 17: 67-88.

Murphy, P. G., and A. E. Lugo. 1986b. Structure and biomass of a subtropical forest in Puerto Rico. Biotropica 18:8996.

Murphy, P., and A. Lugo. 1995. Dry forests in Central America and the Caribbean. Pages 9-34 in S. H. Bullock, H. A. Mooney, and E. Medina, editors. Seasonally dry tropical forests. Cambridge University Press, Cambridge, UK.

Nelson, B. W., R. Mesquita, J. L. G. Pereira, S. G. A. de Souza, G. T. Bastista, and L. B. Couto. 1999. Allometric regressions for improved estimate of secondary forest biomass in the central Amazon. Forest Ecology and Management 117:149-167.

Prance, G. T., W. Balee, B. M. Boom, and R. L. Carneiro. 1987. Quantitative ethnobotany and the case for conservation in Amazonia. Conservation Biology 1:296-310.

Putz, F. E. 1983. Liana biomass and leaf area of a "Tierra Firme" forest in the Rio Negro Basin, Venezuela. Biotropica 15:185-189.

Reyes, G., S. Brown, J. Chapman, and A. E. Lugo. 1992. Wood densities of tropical tree species. USDA Forest Service: Southern Forest Experiment Station. General Technical Report SO-88.

Rich, P. M. 1987. Mechanical structure of the stem of arborescent palms. Botanical Gazette 148:42-50.

Rodriguez Caballero, R. 1944. La explotacion de los Montes de Caoba en el Territorio de Quintana Roo. Thesis. Universidad Autonoma Chapingo, Chapingo, Mexico.

SAS Institute. 1989. SAS/STAT user's guide, version 6. Fourth edition. Volumes 1 and 2. SAS Institute, Cary, North Carolina, USA.

Simpson, W. T., and J. A. Sagoe. 1991. Relative drying times of 650 tropical woods: estimation by green moisture content, specific gravity, and green weight density. USDA Forest Service: Forest Products Laboratory. General Technical Report FPL-GTR-71.

Snook, L. K. 1998. Sustaining harvests of mahogany (Swietenia macrophylla King) from Mexico's Yucatan forests: past, present, and future. Pages 61-80 in R. B. Primack, D. Bray, H. A. Galletti, and I. Paciano, editors. Timber, tourists, and temples: conservation and development in the Maya forests of Belize, Guatemala, and Mexico. Island Press, Washington, D.C., USA.

Sokal, R. R., and F. J. Rohlf. 1995. Biometry: the principles and practices of statistics in biological research. W. H. Freeman, New York, New York, USA.

Steel, R. G. D., and J. H. Torrie. 1980. Principals and procedures of statistics: a biometrical approach. Second edition. McGraw-Hill, New York, New York, USA.

Tomlinson, P. B. 1979. Systematics and ecology of the Palmae. Annual Review of Ecology and Systematics 10:85107.

Trejo, I., and R. Dirzo. 2000. Deforestation of seasonally dry tropical forest: a national and local analysis in Mexico. Biological Conservation 94:133-142.

Turner, B. L., II. 1974. Prehistoric intensive agriculture in the Mayan lowlands. Science 185:118-124.

Turner, B. L., II, et al. 2001. Deforestation in the southern Yucatan peninsular region: an integrative approach. Forest Ecology and Management 154:353-370.

Uhl, C., and C. F. Jordan. 1984. Succession and nutrient dynamics following forest cutting and burning in Amazonia. Ecology 65:1476-1490.

Whigham, D. F., P. Zugasty Towle, E. Cabrera Cano, J. O'Neill, and E. Ley. 1990. The effect of annual variation in precipitation on growth and litter production in a tropical dry forest in the Yucatan of Mexico. Tropical Ecology 31: 23-34. 